\title{
TRANSBOUNDARY CIVIL LITIGATION IN KOREA
}

\author{
Suh Chul Won*
}

\section{INTRODUCTION}

This paper purports to present a concise survey of Korean law and practice relating to transboundary civil litigation. In such a presentation in the English language the problem arises of differences in contents and nuances between Korean and English legal terms. In order to facilitate understanding of the Korean law, an attempt has been made to use, as much as possible, terms popularly used in Anglo-American legal literature. This may, however, not eliminate the existing differences in meaning between certain Korean concepts and their English equivalents.

\section{GENERAL CONTEXT}

\subsection{The judicial system}

Korea, being a unitary state, has a uniform judicial system. The courts in Korea can be classified into courts of limited jurisdiction and those of general jurisdiction. Courts of limited jurisdiction have jurisdiction over certain kinds of subject matter only. Examples are the Constitutional Court, the Martial Court, the Family Court, the Administrative Court and the Patent Court. The Constitutional Court has jurisdiction over such matters as the constitutionality of laws and of acts of government branches, the removal of high-ranking officers, the dissolution of a political party, and jurisdictional conflicts between different branches of government. A Martial Court hears criminal cases involving military or civil members of the Korean Armed Forces. Family Courts adjudicate cases involving family law issues, such as marriage, divorce and adoption. Administrative courts deal with cases involving acts of government of a public law character. The Patent Court is a special court to adjudicate cases involving acts of the Patent Office or issues of intellectual property law. These Courts of limited jurisdiction are already in existence, except the Administrative Court and the Patent Court which are scheduled to be established on 1 March 1998. Apart from the Constitutional

\footnotetext{
* Assistant Professor of Law, Soong Sil University, College of Law, Seoul.

Asian Yearbook of International Law, Volume 6 (Ko Swan Sik et al., eds.

${ }^{\bullet}$ Kluwer Law International; printed in the Netherlands), pp. 169-200
} 
Court, appeal in last resort for cases decided by courts of limited jurisdiction is with the Supreme Court.

Courts of general jurisdiction adjudicate all civil and criminal matters except those falling under the scope of courts of limited jurisdiction. A civil case is dealt with by a court of general jurisdiction, with the exception of family law cases which are dealt with by the Family Court. Questions concerning the constitutionality of laws fall under the jurisdiction of the Constitutional Court.

The three levels of courts of general jurisdiction are the District Court, the High Court and the Supreme Court. The High Court and the Supreme Court are exclusively panel courts. A District Court may act as a singlejudge court as well as a 3-judge panel court. The District Court has original jurisdiction in civil cases. The character of a case determines whether the first instance court is a single-judge court or a panel court. Panel court cases are: (a) cases involving amounts exceeding 30 million won (about US\$ 30,000 ), except cases arising from check and bill of exchange relationships which are always single-judge cases regardless of the amount involved ${ }^{1}$ (b) property cases, the sum of which is incalculable; ${ }^{2}$ (c) cases concerning immaterial rights; ${ }^{3}$ (d) cases classified as panel court cases by a panel court; ${ }^{4}$ (e) categories of cases classified as panel court cases by the law; ${ }^{5}$ (f) multiclaim cases one of which is under the jurisdiction of a panel court. A panel court case may be adjudicated by a single-judge court upon a corresponding decision by the panel court. ${ }^{6}$

A judgment by a first instance court may be reviewed twice - by the intermediate appellate court and by the last resort appellate court. The intermediate appellate court reviews the judgments of first instance courts not only on the legal issues but also on those of a factual nature. The review is invoked by appeal from a party. There are no limits to the right of appeal to the intermediate appellate court. The last resort appellate court reviews legal issues only. This review is also invoked by appeal from a party. There is no system of certiorari, but in order to prevent overburdening of the court, small claims and cases with no real legal issues involved are excluded from its appellate jurisdiction. The Supreme Court is the last resort appellate court.

Which court serves as intermediate appellate court depends on the kind of first instance court. If the first instance court is a single-judge chamber of the District Court, the panel chamber of the District Court serves as intermediate

\footnotetext{
${ }^{1}$ Supreme Court Regulation on Material Jurisdiction in Civil and Family Litigation (Supreme Court Reg. 706 of 14 January 1980), Art. 2(1).

${ }^{2}$ Ibid.

${ }^{3}$ Regulation on Material Jurisdiction, Art. 2(2).

${ }^{4}$ Court Organization Act (Act No. 3992 of 4 December 1987), Art. 32(1)(1).

${ }^{5}$ Court Organization Act, Art. 32(1)(6).

${ }^{6}$ Regulation on Material Jurisdiction, Art. 2(1).
} 
appellate court. ${ }^{7}$ If the first instance court is a panel chamber of the District Court, the intermediate appellate court is the High Court. ${ }^{8}$ One of the characteristics of the Korean judicial system is that trial and appellate jurisdiction may be exercised by the same court.

There is no special court for transboundary civil cases in Korea. However, in view of the increasing number of transboundary litigations, special divisions for this category of litigation have been set up in the Seoul District Court and in the Seoul High Court. In the Seoul District Court, 2 panel chambers and 2 single-judge chambers were established on 1 March 1994, under the name of "Special Division for International Transactions and Special Commerce Cases". In the Seoul High Court, the 1st and 12th Civil Cases Divisions were designated special divisions for transboundary civil litigation on 1 March 1996. No such special divisions exist in the other courts. $^{9}$

Except by adjudication, civil disputes can also be concluded by other methods, such as arbitration, conciliation and settlement. Arbitration will be dealt with in section 7 of this paper. Settlement can be subdivided into private settlement and court settlement. Private settlement means that the dispute is settled by agreement between the parties. The general law on contract applies to such an agreement. No special form or specific content is required for a settlement agreement to be valid, and consequently, 'seal' or 'consideration' requirements as exist in the Anglo-American legal system do not apply. If, however, a settlement is the result of an unreasonable exercise of economic supremacy, it may be declared invalid for being in breach of a good moral or social order. ${ }^{10}$

There are two kinds of court settlement: pre-trial settlement and in-trial settlement. In the case of pre-trial settlement, the District Court upon request of the parties provides its good offices and supervises the efforts through one of its judges, leading to the dispute being settled by agreement between the parties. The agreement reached has the effect of a final judgment. ${ }^{11}$ The applicable procedure is laid down in Articles 355-359 of the Korean Civil Procedure Code (KCPC). In-trial settlement refers to settlement of the dispute during the trial. Here too the dispute is settled by agreement between the

\footnotetext{
${ }^{7}$ Court Organization Act, Art. 32(2)(1).

${ }^{8}$ Court Organization Act, Art. 281(1).

${ }^{9}$ As to the activities of the special divisions of the Seoul District Court, reference is made to its 21st and 22nd divisions. Kukjekeorae mit Sangsasakeon Jeondamjaepanbu [Special Division on International Transactions and Special Commerce Cases], Inkwonkwa Jeongeui [Human Rights and Justice] (April 1995) 133.

${ }^{10}$ LeE SIYOON, Minsasosongbub [Civil Procedure Law] (Bakyungsa, 1995) 21.

${ }^{11}$ Korean Civil Procedure Code (Act No. 547 of 4 April 1960), Art. 206.
} 
parties with permission from the court where the case is pending, and the agreement has the effect of a final judgment. ${ }^{12}$

As to conciliation, there are again two kinds: conciliation by the court and conciliation by a government agency. Both may either be consensual or compulsory. Conciliation by a government agency has been institutionalized in various fields, such as environment protection, consumer protection, labour disputes and medical disputes. Consensual conciliation begins with the request of both parties to the dispute. Compulsory conciliation begins either with the request by the injured party or through a motion of the agency itself. Both types of conciliation do not take effect without the consent of both parties to the recommendations made.

Conciliation by the court is regulated by law, for example in the Civil Conciliation $\mathrm{Act}^{13}$ or the Family Conciliation section of the Family Litigation Procedure Code. ${ }^{14}$ All kinds of civil disputes may be settled by conciliation. It begins with a request to a District Court either by both parties or by one of the parties to the dispute, or on authority of the court where the case is pending. ${ }^{15}$ The motion may be made at any time up to the end of the pleadings. ${ }^{16}$ The provisions on regional jurisdiction (in the literature some- times referred to as jurisdiction ratione loci) apply in case of conciliation at the request of a party. ${ }^{17}$ In this case, a judge in charge of conciliation or a conciliation committee of the court hears the case. In case of conciliation on authority of the court, the competent court is the one where the case is pending.

If no agreement can be reached, the judge or committee may propose a compromise whenever deemed proper. The compromise takes effect if both parties do not file objections within 2 weeks. ${ }^{18}$ The agreement reached through conciliation by court has the effect of a final judgment. ${ }^{19}$ If no agreement is reached, nor a compromise proposed, or if an objection to the compromise proposal is filed, then the original request for conciliation is regarded as the filing of a lawsuit. ${ }^{20}$

\footnotetext{
${ }^{12}$ Ibid. Art. 206.

${ }^{13}$ Act No. 4202 of 13 January 1990.

${ }^{14}$ Act No. 4300 of 31 December 1990.

${ }^{15}$ Civil Conciliation Act, Art. 6.

${ }^{16}$ Civil Conciliation Act, Art. 1706.

${ }^{17}$ Ibid., Art. 3.

${ }^{18}$ Ibid., Art. 34.

${ }^{19}$ Ibid., Art. 29.

${ }^{20}$ Ibid., Art. 36.
} 


\subsection{Sources of law}

Korea is a civil law country profoundly influenced by the German and Japanese legal systems. As is usual in a civil law country, the basic laws, including those on civil procedure, are systematically codified. The substantive law applicable to transboundary civil relationships is determined by applying the rules of private international law. In Korea this law is systematically codified in the Private International Law Act or, after its Korean name, the 'Excavational Law Act' ${ }^{21}$ There is, however, no systematic code of the law of procedure relating to transboundary civil litigation. Provisions are scattered over various codes or acts. Some are to be found in the Korean Civil Procedure Code, such as provisions on regional jurisdiction (jurisdiction ratione loci) over foreign legal persons (Art. 4 para. 2), the legal capacity of foreigners to litigate (Art. 53), the method of service in a foreign country (Art. 176), service by public notice (Art. 179), the effect of foreign judgments (Art. 203), the taking of evidence in a foreign country (Art. 268), the presumption of authenticity of foreign official documents (Art. 327 para. 3), the execution of foreign judgments (Arts. 476 and 477) and the seizure of foreign vessels (Art. 688). International judicial cooperation in civil matters is regulated in a separate statute. ${ }^{22}$ Other important matters are not regulated by any existing statutory law.

The question is whether the law on (principally domestic) civil procedure applies to transboundary civil litigation as well. A current school of thought answers affirmatively, precisely because there is no indication that the KCPC is supposed to apply to domestic cases only. ${ }^{23}$ It is argued that the absence of a specific provision prescribing such limitation and the only partly available specific provisions on transboundary litigation should lead to the conclusion that all general provisions are to be interpreted as being applicable not only to domestic litigation but also to transboundary litigation, with the exception of provisions whose scope of application specifically excludes transboundary civil litigation. This view has been criticised as not taking sufficient account of the difference between domestic and international cases. The latter school of thought argues that the KCPC applies to transboundary civil cases only if the transboundary characteristics of the case do not indicate otherwise ${ }^{24}$ The controversy is especially serious with respect to the issue of international jurisdiction, which will be dealt with below in sub-section 3.2.

\footnotetext{
${ }^{21}$ Act No. 966 of 15 January 1962. It is strongly influenced by the Japanese Act on Private International Law.

${ }^{22}$ The Act on International Judicial Cooperation in Civil Cases (Act No. 4342 of 8 March 1991).

${ }^{23}$ Chung Dongyoon, Minsasosongbub [Civil Procedure Law] (Bubmunsa, 1995) 110.

${ }^{24}$ CHOI Kongwoong, Kukjesosong [International Litigation] (Yookbubsa, 1994) 234.
} 
Besides the above-mentioned statutes, there are a number of Supreme Court regulations on civil litigation. The Korean Constitution empowers the Supreme Court to make regulations with legally binding force provided they do not violate statutory law.

Korea is not a party to any multilateral treaty on transboundary civil litigation. As to bilateral treaties, it is only in the field of criminal law that Korea has recently concluded judicial cooperation treaties with the US, Australia and Canada.

The fact that Korea is a civil law country does not exclude the possibility and importance of judge-made law. Though judicial decisions have no generally binding force, they play an important role in the interpretation of the written law and in filling up lacunae. Their importance is particularly great in the field of procedural law relating to transboundary civil litigation, as there are a great many gaps in the written law on the matter.

The opinion of scholars is also important in the law of procedure in transboundary civil litigation. As there have not been many such litigations in Korea, there are not enough judicial decisions yet to provide sufficient predictability of Korean practice on all relevant issues. In such cases the opinion of scholars is the last resort in predicting possible judgment. Actually, there are several examples of opinions of scholars to which reference has been made in judicial decisions.

With regard to the question of the applicable procedural law, it is generally recognized in Korea that the lex fori is applicable in transboundary civil litigation. ${ }^{25}$ The problem is how to distinguish between substantive and procedural matters. According to the current school of thought in Korea, this is determined through application of the legal criteria of the forum state, although the result may be modified by jori (see infra, sub-section 3.2.1) in view of the specific features of a transboundary procedure. ${ }^{26}$

\section{JURISDICTION}

\subsection{Notion of jurisdiction}

The term jurisdiction is used in several meanings in Korea. It may refer to the competence of a state to exercise prescriptive, adjudicative or enforcing power. In transboundary civil litigation it refers to the adjudicative competence of a state to hear and decide a case, which is equivalent to juris-diction in US legal terminology. The terms 'general jurisdiction', 'general competence' and 'international jurisdiction' are used to specify this meaning. ${ }^{27}$ In this paper, the term 'international jurisdiction' is employed.

\footnotetext{
${ }^{25}$ Ibid. p. 244; CHUNG DONGYOON, op. cit. n. 23 p. 110.

${ }^{26}$ CHOI KongwOONG, op. cit. n. 24 p. 247.

${ }^{27}$ SUH HEEWON, Kukjesabubkangeui [Lectures on private international law] (Ilchogak, 1996)
} 
International jurisdiction can be relevant in a direct or indirect way. The issue may be whether the judiciary of a country has competence to hear a given transboundary civil case. The term 'direct international jurisdiction' is employed to refer to this meaning. The notion of international jurisdiction may also be relevant as a requirement in recognizing and enforcing a foreign judgment. The term 'indirect international jurisdiction' is used to specify that meaning. Although a different term is used, the basic idea underlying both jurisdictions is said to be the same. ${ }^{28}$

The term jurisdiction is also used to refer to the competence of a specific Korean court to adjudicate a given case, on the presumption that the Korean judiciary has international jurisdiction. For this purpose, terms like 'specific jurisdiction', 'specific competence', 'concrete jurisdiction' and 'domestic jurisdiction' are employed. ${ }^{29}$ This paper uses the term 'domestic jurisdiction'.

Domestic jurisdiction in Korea can be categorized in various ways. First, there is the categorization according to the basis of jurisdiction. Under this categorization, jurisdiction can be sub-divided into law-deciding jurisdiction, court-deciding jurisdiction and party-deciding jurisdiction. Law-deciding jurisdiction refers to jurisdiction based on the distribution of cases among the courts and can be sub-categorized into functional, material and regional jurisdiction. Court-deciding jurisdiction refers to the jurisdiction of a higher court to decide in a dispute over, or uncertainty about, jurisdiction of a lower court. Party-deciding jurisdiction refers to jurisdiction on the basis of the will of the parties. It can be sub-divided into jurisdiction by acquiescence and consensual jurisdiction.

The second categorization distinguishes between exclusive and optional jurisdiction. Exclusive jurisdiction refers to jurisdiction that may not be set aside, irrespective of the consent of the parties concerned. It applies where such public interests as fair trial or due process demand adjudication of the case by a specific court. Functional jurisdiction, as mentioned below, is usually exclusive, unless the law provides otherwise, for example where a so-called jumping appeal is allowed. Optional jurisdiction may be substituted by another by consent of the parties concerned, since it is provided for the benefit of the private interests of the parties concerned, such as convenience or equal opportunity of the parties. Material jurisdiction and regional jurisdiction $^{30}$ are usually optional, except where the law provides otherwise.

Functional jurisdiction refers to the distribution of functions among various courts. One may distinguish between the functions of adjudication and execution, or may refer to the different functions of single-judge courts

\footnotetext{
120.

${ }^{28}$ Chung Dongyoon, op. cit. n. 23 p. 109.

${ }^{29}$ CHOI Kongwoong, op. cit. n. 24 p. 268.

${ }^{30}$ See infra.
} 
and panel courts, or to the different levels of courts. An adjudication court assumes functions like taking and preserving evidence, and ordering provisional attachment. An execution court entertains functions like compulsory execution of property and supervision of the process. An execution court is usually a single-judge court.

The distribution of functional jurisdiction among single-judge courts and panel courts refers to the distribution of various functions relating not only to trial procedures but also to appellate procedures, and to pre-trial and postjudgment matters as well. The general rule is that single-judge courts assume jurisdiction over issues that are simple and require a speedy decision, while panel courts adjudge issues that are complex and require careful consideration. Exclusion and challenge of judges are typical examples of the functions of a panel court. Pre-trial settlement, preservation of evidence, special speedy trial ${ }^{31}$ and questions of public notice are salient examples of singlejudge court functions. Functional assignment of jurisdiction may take place for a case falling under the material jurisdiction of another court.

Level jurisdiction refers to the different functions of the various levels of courts. The function of every court at any level begins with the filing of the suit or the appeal and ends with the delivery of judgment. Before a higher court begins its functions by filing the appeal and transferring the relevant documents from the lower court, actions such as provisional attachment and preservation of evidence remain under the responsibility of the lower court.

Regional jurisdiction (or jurisdiction ratione loci) refers to the distribution of cases among courts of the same level in different districts. It is similar to 'venue' in the US legal system. It is decided by various factors connecting the court and the case concerned. These factors can be categorized in two ways. First, categorization may take place by distinguishing between factors ratione personae and those ratione materiae. Jurisdiction ratione personae relates to the connection between the court and the parties concerned, typical examples of which are residence and domicile. Jurisdiction ratione materiae concerns the connection between the court and the facts of the case concerned, such as the place of commission of the tort or the place of first arrival of the salvaged ship. A second categorization is the distinction between general factors and special factors. General factors apply to all the civil litigations of a person, regardless of their factual aspects, whereas special factors apply to specific kinds of claims.

A tort suit may be brought in the court of the place where the act was committed. ${ }^{32} \mathrm{~A}$ lawsuit for damages due to a collision of vessels or aircraft or any other accident relating to vessels or aircraft, may be brought in the court

\footnotetext{
${ }^{31}$ Under this procedure the court may issue an order for the payment of an alleged debt without hearing the debtor. The latter may follow the order or may raise objection. In the latter case a formal trial will follow. The Supreme Court Office uses the English translation "demanding procedure" for the Korean term.

${ }^{32} \mathrm{KCPC}$, Art. 16(1).
} 
of the place where the damaged vessel or aircraft first arrived..$^{33} \mathrm{~A}$ suit relating to salvage may be brought in the court of the place where the salvage was effected or the place where the salvaged vessel first landed. ${ }^{34} \mathrm{~A}$ suit relating to a right of succession, a testamentary gift or any act that is to take effect by death, may be brought in the court of the place where the deceased was at the time of the opening of the succession. ${ }^{35}$ A suit relating to a claim against the estate of a deceased or relating to an incumbrance upon such estate may also be brought in the court where the deceased was at the time of the opening, but only when the whole or part of the estate lies in the jurisdictional district of that court. ${ }^{36}$

\subsection{Exercise of jurisdiction}

\subsubsection{Requirements}

The first thing to note regarding the requirements for international jurisdiction of Korean courts is that the KCPC does not deal with them directly. It only contains provisions on domestic jurisdiction. The Korean Private International Law Act contains special provisions on the requirements for international jurisdiction of Korean courts only in some specific cases, such as the declaration of incompetence and its revocation, and the appointment and removal of guardians for incompetent persons. ${ }^{37}$

How then should an answer be found to the question whether a Korean court has international jurisdiction? There are two prominent schools of thought in Korean scholastic opinion. One school argues that the problem should be solved by analogy, i.e. by applying the KCPC provisions on domestic jurisdiction. ${ }^{38}$ According to this view, one should first ask whether, if the case were a domestic one, the court would have jurisdiction under the $\mathrm{KCPC}$. If the answer is in the affirmative, the Korean court also has jurisdiction in transboundary cases. This school of thought is called the 'Nationalist School'. Another school of thought argues that the issue should be settled by applying jori on transboundary civil litigation. ${ }^{39}$ Jori may be translated into

\footnotetext{
${ }^{33} \mathrm{KCPC}$, Art. 16(2).

${ }^{34} \mathrm{KCPC}$, Art. 17.

${ }^{35} \mathrm{KCPC}$, Art. 20.

${ }^{36} \mathrm{KCPC}$, Art. 21.

${ }^{37}$ Korean Private International Law Act, Arts. 7(2), 8 and 25(2).

${ }^{38}$ LEE SIYOON, op. cit. n. 10 p. 60; CHUNG DONGYoON, op. cit. n. 23 p. 114; LEE YounGSEOP, Sinminsasosongbub [New Civil Procedure Law] (Bubmunsa, 1972) 61.

${ }^{39}$ KANG HYUNJOONG, 'Kukjeminsasosongbub' [International civil procedure law], Sabubhaengjung [Judicial Administration] (April 1987) 48; CHOI KONGWOONG, op. cit. n. 24 p. 300.
} 
'legal reasoning' or 'natural law'. It is a very vague notion which emphasizes the need for due respect to international comity, due process of law, fair opportunity for the parties concerned, and speedy and efficient trial. This school of thought is called the 'Internationalist School'.

The Internationalist School criticizes the Nationalist School for putting the cart before the horse. It argues that international jurisdiction should be affirmed before the issue of domestic jurisdiction becomes relevant. The Internationalist School emphasizes the different rationale of international and domestic jurisdiction and holds that there is no reason why international jurisdiction should be dependent on domestic jurisdiction. However, the Internationalist School is also not free from criticism. The Nationalist School argues that the theory of the Internationalist School is too vague and that the core notion of jori cannot provide sufficient criteria for the court to decide on the issue of its international jurisdiction.

The Korean courts seem to espouse, roughly speaking, a compromise view. Accordingly, the court first analyses whether the court's domestic regional jurisdiction would be established if the case were a domestic one. Next, the court considers whether jori would change the result of the application of the general rule. Through this process, full account is taken of the characteristics of transboundary civil litigation. The degree of the effect of jori and its nuances are, however, not uniform. The following decisions of the Supreme Court may illustrate this.

A transboundary case on broker fees arose out of a broker agreement in respect of an international financial transaction concluded between a Korean company and a Japanese company in Japan. The Supreme Court recognized the Korean court's international jurisdiction. The reasoning reads, inter alia:

\begin{abstract}
"Art. 6 of the KCPC provides that a claim relating to a property right out of contract may.be brought before the court of the place of performance. According to the Korean Private International Law Act, the applicable law is Japanese commercial law, the law of the place where the contract was concluded, since no special agreement on the applicable law is provided in the contract. The Japanese Commercial Code provides that, except in case of an obligation to deliver specific goods, the place of performance of the contract is the domicile of obligee. The Japanese company established a subsidiary in Seoul, Korea to manage the work concerned. Under these conditions, the judiciary of Korea, being the place of performance, has international jurisdiction, barring any special provision to the contrary." 40
\end{abstract}

Through this reasoning the Supreme Court decided on the issue of international jurisdiction by applying the provisions on domestic regional jurisdiction by analogy.

${ }^{40}$ Supreme Court, 20 April 1972, Pankyul [Judgment] Da 248. 
In a divorce case between foreigners jori was more emphasized. ${ }^{41}$ The plaintiff was an American citizen who had lived in Korea since 1964. The defendant was also an American, with domicile in the US. The Korean Family Litigation Procedure Code $^{42}$ stipulates that, unless otherwise provided, a family lawsuit shall be brought in a court which is the general forum of the defendant. It also provides that this general forum is determined by the defendant's residence, domicile or last domicile, and that, if there is no such place, the proper court is the family court of the place where the Supreme Court is located. Considering the nationality and domicile of the parties and the above provision, the Supreme Court denied international jurisdiction of Korean courts in the case, even though the proper court might be the family court of the place where the Supreme Court is located, if the case were a domestic one. The reason provided was that in a divorce case between aliens, Korean courts have international jurisdiction only if the domicile of the defendant is located in Korea, barring special circumstances to the contrary.

However, there is another decision according to which the case is presumed to meet the jori on international jurisdiction if it meets the requirements of the KCPC on domestic regional jurisdiction. An officer of the Korean branch of a foreign company filed a lawsuit on grounds of unlawful dismissal. On the issue of international jurisdiction of the Korean court, the Supreme Court held:

"As no treaty on international jurisdiction is concluded, as no generally recognized principle of international law on international jurisdiction is established, and no provision on international jurisdiction is provided by the KCPC, this issue should be decided by jori, having due consideration of fairness for the parties concerned and of a speedy and faithful trial. In this regard, it should be acknowledged that if the requirements of the KCPC provision on domestic jurisdiction are met, the requirements of international jurisdiction are deemed to be met also, as the KCPC provisions are made in accordance with the above-mentioned jori." 43

For this reason, international jurisdiction over the case was recognized by analogy of Article 10 of the KCPC. This Article provides that a suit against a person holding office or other place of business at some place may, insofar as the claim exclusively concerns the business affairs of such office or place of business, be brought before the court of the place where the office or place of business is situated.

The principle adhered to in the above decision was re-affirmed in a recent case, as follows:

\footnotetext{
${ }^{41}$ Supreme Court, 22 July 1975, Pankyul Meu 22.

${ }^{42}$ Act No. 4300.

${ }^{43}$ Supreme Court, 20 July 1992, Seongo 91 Da 41897.
} 


\begin{abstract}
"As there is no provision in the $\mathrm{KCPC}$ on international jurisdiction, nor a treaty or a relevant generally recognized [rule of] inter-national law, [the question] should be settled by jori on inter-national jurisdiction consisting of fairness for the parties con-cerned and a speedy and faithful trial. As the provisions on domestic regional jurisdiction of the KCPC follow the jori, it is reasonable that if one of such factors as the domicile of the defendant, the office of the legal person, the place of performance, the location of the property, or the place of commission of the tort is in Korea, the international jurisdiction of the Korean judiciary is presumed, barring special circumstance to the contrary." 44
\end{abstract}

From the above cases it may be inferred that, if a case includes one of the factors required by the KCPC for the determination of domestic regional jurisdiction, the existence of international jurisdiction is presumed unless the jori on international jurisdiction demands otherwise. The divorce case also seems to infer that jori is more emphasized in family law cases.

As the provisions on domestic regional jurisdiction play an important role, it is necessary to elaborate on them. They are laid down in Articles 1-2 [Art. 1a according to Western usage] to 21. Articles 1-2 and 2 relate to general regional jurisdiction over natural persons. Articles 3 to 5 concern general regional jurisdiction over Korean diplomatic officers, Korean legal persons and the Korean government respectively. Articles 6 to 21 are provisions on special regional jurisdiction, which means that they apply only to such special kinds of cases as tort, claims relating to immovable property and claims relating to salvage.

Several factors, such as the domicile of the defendant and the place of tort, may apply to a case so that several courts may have regional jurisdiction over the case. In these situations the plaintiff may choose among the eligible courts. The choice of the plaintiff is, however, not final and he may file the same suit at another court. The result is that it may lead to lis pendens with the effect of dismissal or suspension of the later suit.

\title{
3.2.2. Exercise of jurisdiction in case of non-fulfilment of jurisdictional requirements
}

If a claim seeks the determination of personal liability of the defendant, his appearance in court to contest the case on its merits constitutes submission to the jurisdiction of the court, even when jurisdiction would not have existed otherwise. This basis of jurisdiction is called general appearance or jurisdiction by acquiescence. There is no rule on international jurisdiction by acquiescence in the KCPC which only contains a provision on domestic jurisdiction by acquiescence:

${ }^{44}$ Seoul District Court, 12 January 1996, Seongo 64 KaHab 66533. 
"When a defendant pleads on the merits of a suit or makes statements in the preliminary proceedings without contesting the jurisdiction of the court of first instance, the said court shall have jurisdiction."

There is no court decision on whether jurisdiction by acquiescence is recognized with respect to international jurisdiction. It is presumed, however, that if a case meets the requirements of domestic jurisdiction by acquiescence and if jori on international jurisdiction does not demand otherwise, international jurisdiction by acquiescence would be recognized. ${ }^{45}$ This is inferred from the judicial decisions on the relationship between domestic jurisdiction and international jurisdiction. Therefore, it is necessary to elucidate the requirements and effects of domestic jurisdiction by acquiescence.

Jurisdiction by acquiescence is recognized only in cases of optional jurisdiction. It takes effect when the defendant pleads on the merits without making jurisdictional pleas. Jurisdictional pleas after pleading on the merits cannot prevent the effect of the jurisdiction vested by acquiescence. It has effect only for the case concerned, and not for a renewed suit filed after dismissal of the original one on the notion of the court or upon the request of the plaintiff.

Joinder of causes of action or of parties may be a ground for establishment of jurisdiction. It could mean that even though a court has no domestic regional jurisdiction over a claim, yet it may exercise jurisdiction if the court has jurisdiction over other claims co-related to the former one. Article 22 of the KCPC provides as follows:

“(1) In the case of joinder of several claims in one suit, such a suit may be brought in any court having jurisdiction over any one of the claims in accordance with the provisions of Articles 1-2, 2 to 5, 5-2, 6 to 21.

(2) The provision of Paragraph (1) shall be applicable in case the right or duty which is the object of the lawsuit is common to more than one person, or if several persons become parties as common litigants due to the same actual or legal cause."

This provision is interpreted as giving rise to new jurisdiction in a multiparty case if the legal or factual bases of the original claims are co-related. In a multi-claim case between the same parties, however, co-related jurisdiction is recognized although there is no common factual or legal basis between the various claims. The provision applies only to regional jurisdiction and not to other jurisdictions, such as functional, material or level jurisdiction.

Though the provision is designed to apply only to domestic jurisdiction, it has been acknowledged by the Supreme Court that joinder of causes of action

${ }^{45}$ CHOI Kongwoong, op. cit. n. 24 p. 308. 
creates new jurisdiction also in transboundary litigation. The defendant in the case concerned requested attachment and auction of plaintiff's property in Korea. The plaintiff filed a counter-claim, the cause of which was related to the basis of attachment. In regard to the counter-claim, the defendant made a jurisdictional plea that the Korean court had no international jurisdiction. The Supreme Court rejected the plea by ruling that:

"Contrary to his argument that the Korean court has no international jurisdiction diction over him, the defendant, a foreign company, has submitted to the jurisdiction of the Korean court by requesting attachment and auction to a Korean court. Therefore, in light of jori, it would be reasonable for the Korean court to exercise international jurisdiction over the case of which the facts are related to the basis of the attachment and auction." 46

Thus international jurisdiction was assumed in case of joinder of causes of action. It is not certain whether international jurisdiction would also be assumed in case of joinder of parties, but it is likely to be the case if the claims have a common factual or legal basis.

\subsubsection{Jurisdiction of compulsory execution}

The Korean legal system does not recognize civil arrest in the sense of public authority taking a person in custody for the purpose of forcing him to answer to a civil claim. Compulsory execution in the Korean legal system can be divided into direct execution, substituted execution, and indirect execution. Direct execution is performed by public authority in regard to the object of the judgment. Substituted execution is performed by public authority in regard to another object when the execution of the original object is considered not feasible by the executing court. Indirect execution aims at compelling the defeated party to perform or to refrain from some act by threatening to impose disadvantages on him. In that respect it is similar to civil arrest, but the only disadvantage that can be imposed in the Korean legal system is that of punitive damages.

The jurisdiction to perform substituted execution and indirect execution is exercised exclusively by the court which has rendered the judgment. ${ }^{47}$ The jurisdiction of direct execution is exercised by the public execution authority or court of the place where the object of the execution is located. The Court with jurisdiction over direct execution deals with compulsory auction of immovable property and direct execution of contract rights of the original obligor against a third-party obligor, and other property rights. ${ }^{48}$ The public execution authority deals with other compulsory executions such as provisional attachment, provisional execution or compulsory auction of tangible

\footnotetext{
${ }^{46}$ Supreme Court, 12 December 1989, Seongo 88 DaKa 3391.

${ }^{47} \mathrm{KCPC}$, Art. 693.

${ }^{48} \mathrm{KCPC}$, Arts. 557 and 667.
} 
and movable property, compulsory execution of or conveyance of immovable or movable property. ${ }^{49}$

\subsubsection{Jurisdiction in rem and quasi in rem}

In rem action in the US legal system purports to affect the interests of persons in a specific thing, instead of imposing personal liability on anyone. The effect is that the possible judgment only determines the status of a thing adjudicated. The intended result is reflected only in certain kinds of action, such as an action for the confirmation of title or confirmation of paternity. This notion is unknown in the Korean legal system. The jurisdictional effect of in rem jurisdiction is that the court which does not have personal jurisdiction may exercise jurisdiction by the mere fact that the thing adjudicated is located in the district. Such reasoning is reflected in some provisions on regional jurisdiction, including Articles 9, 18 and 19 of the KCPC.

Quasi in rem action in the US legal system refers to an action that would have been in personam if jurisdiction over the defendant had been attainable. It is referred to as half-way house between in rem and in personam. It is in rem in that the court is able to exercise jurisdiction because the defendant has property within the jurisdiction. It is in personam in that the subject matter of the suit is unrelated to the property seized. The characteristic of quasi in rem action is that property and intangibles are seized not as the real object of the litigation, but merely as a means of establishing jurisdiction over the defendant. A judgment quasi in rem has no res judicata value as the court has not exercised jurisdiction with regard to personal liability. That notion is also unknown and is in fact unnecessary in the Korean legal system. Because of the uniform character of the Korean judicial system, the judgment of a Korean court is valid in all other courts in Korea. The scope of the judgment depends exclusively on the mode of judgment and the intention of the court.

Things may, however, be different in transboundary civil litigation. As a Korean judgment is not always recognized in foreign countries, it may be enforced only by execution of property located in Korea. In such a situation, quasi in rem jurisdiction may be at issue. In this regard, Articles 9 and 12 of the KCPC become relevant. Article 9 provides, in part, that an action concerning property rights against a person who has no domicile in Korea, or whose domicile is unknown, may be brought before the court of the place where attachable property of the defendant is situated. Article 12 provides that an action based on an obligation related to or secured by a vessel may be brought in the court of the place where the vessel is situated. Since the court may have no other connecting factor for its jurisdiction, the effect of a possible judgment is similar to that of a quasi in rem action. In fact the

${ }^{49} \mathrm{KCPC}$, Arts. 492, 527, 689 and 690. 
Supreme Court has recognized that Article 9 applies to transboundary civil litigation:

"A property right action against a person who has no domicile in Korea, or whose domicile is unknown, may be brought before the court located in the place where the subject matter or the security therefor, or any attachable property of the defendant is situated, even though he is a foreigner. The reason for the recognition of this jurisdiction is that the possible judgment will be enforced by the execution of such property." 50

\title{
3.2.5. Constraints on the exercise of jurisdiction
}

Although jurisdiction might formally exist, special factors might constrain its exercise. This section will deal with two of the most frequently occurring factors: forum non conveniens and 'political question'.

The doctrine of forum non conveniens in the US legal system is defined as the discretionary power of a court to decline to exercise the jurisdiction it possesses when it appears that it may be more appropriate for the case before it to be tried elsewhere. In the Piper Aircraft case, the US Supreme Court held that this doctrine applies to international civil litigation. The rationale of the doctrine is to avoid unreasonable inconvenience for the parties and the burdening of the court with cases unconnected to it. In the Korean legal system, the term forum non conveniens is not used and there is no provision dealing with it. However, the transfer of a suit may meet the rationale of forum non conveniens. Article 32 of the KCPC provides:

\begin{abstract}
"A court may, if it deems necessary to avoid considerable damage or delay in regard to a suit over which it has jurisdiction, transfer the whole or part of such suit to another competent court upon its own authority or upon motion of parties, except in case of a lawsuit under exclusive jurisdiction of the court."
\end{abstract}

Since the provision is designed for domestic jurisdiction, there is uncertainty as to whether and under what conditions it is applicable to international jurisdiction. There is no judicial decision on the issue. Some scholars argue that the policy consideration of forum non conveniens should be applied to international jurisdiction whenever exercise of jurisdiction would result in an unreasonable burden on the defendant. ${ }^{51}$

'Political questions' also constitute a constraint on the exercise of judicial jurisdiction. In the Korean legal system, the doctrine of political question means that the court refrains from the exercise of its jurisdiction in highly political matters. The act of state doctrine is, however, not included. In the

\footnotetext{
${ }^{50}$ Supreme Court, 25 October 1988, Seongo 87 Ka 1728.

${ }^{51}$ RYU YUNGIL, Kukjeminsasabubkongjoe Kwanhan Yunku [A Study on International Assistance and Cooperation in Civil and Commercial Matters], doctoral dissertation (Seoul National University, 1994) 34.
} 
US legal system this doctrine means that an act of a state carried out within its own territory cannot be challenged in the domestic courts of another state. Such a doctrine is not recognized in Korea. Korean courts would decide on the validity of an act of a foreign state (under the law applicable in the case) whenever the issue is raised. International comity is usually considered by recognizing the validity of the act unless it is contrary to the good morals or public policy of Korea.

\subsection{Forum selection}

Article 26 of the KCPC provides the following on forum selection:

"(1) Parties in a case may decide on a first instance court by agreement.

(2) The agreement referred to in Paragraph (1) shall be valid only if it is made in writing with respect to a suit based on a specific legal relationship."

This provision is interpreted to apply only to optional jurisdiction. In the absence of relevant court decisions it is presumed that the requirement of specification of a court is considered to be fulfilled if a specific court can be determined by interpretation of the agreement, even if it does not specifically designate a court. Consequently it would seem that a forum selection is valid even though it only refers to a country, provided the competent court can be determined under the law of the forum state. The right of selection is available in all civil cases, including family cases. The only aspect of the issue treated in scholastic opinion is the invalidity of the selection if it is the result of unreasonable exercise of power by one of the parties.

As the rule formally applies to domestic jurisdiction, scholastic opinion and court decisions are important in determining its applicability to international jurisdiction. It seems that forum selection is indeed considered applicable also to transboundary civil litigation, as soon as the requirements for domestic forum selection are fulfilled. ${ }^{52}$ There is no court decision on whether forum selection is restricted to some special kinds of transboundary issues, and there seems, in fact, to be no such limitation.

Forum selection may, however, not be recognized if it were to result in a denial of justice. ${ }^{53}$ Accordingly, a forum selection cannot bar the filing of a suit in another forum than the one selected, if the selected forum refuses to entertain the selection and to exercise jurisdiction. This reasoning has been well illustrated in a lower court decision. The issue at hand was the validity

\footnotetext{
${ }^{52}$ Chol Kongwoong, op. cit. n. 24 p. 307.

${ }^{53}$ Ibid.
} 
and effect of a forum agreement in transboundary civil litigation. The plaintiff and defendant had agreed on a forum selection clause in an international financial transaction contract, designating the District Court of Tokyo as the proper forum. In spite of the clause, the plaintiff filed a suit in the Seoul Civil District Court in Korea. The defendant made a jurisdictional objection. The court upheld this objection for the following reasons:

“. . . The case before it is not subject to the exclusive jurisdiction of the Korean courts. It is certain that the Japanese court would entertain the case, as the Japanese court does not reject a forum selection in a case where a Japanese company demands payment of capital and interest arising out of a financial transaction contract concluded in Japan between a Japanese company and a Korean company." 54

The nexus between the case and the selected forum is relevant for determining whether the original jurisdiction is optional and, consequently, the forum selection is allowed, and whether the selected forum will recognize the selection made. The forum selection agreement may contain an express provision as to whether the selected forum is intended to be exclusive or cumulative to the statutory forum. In the above case the explicit intention of the parties was entertained. In the absence of such express intention, the Supreme Court decided that if the selected forum is among the law-deciding forums it is exclusive, while it is cumulative if it is not one of them. ${ }^{55}$

Whether the parties may derogate from their own selection depends on whether the initially selected jurisdiction is exclusive or cumulative. In the above-mentioned decision, the court admitted the jurisdictional plea, as follows:

"From the facts presented, the forum selection seems not to be cumulative to that of the Korean judiciary but an exclusive jurisdiction of the Japanese court [. . . .." ${ }^{56}$

As in domestic cases, forum selection in transboundary cases should be done in writing.

\subsection{Lis (alibi) pendens}

Article 234 of the KCPC prohibits the filing of a double suit: "With regard to a case pending before a court, neither party may bring another suit on the [same] case". This provision is considered not to apply to a duplicate suit in the court of a foreign state because the territorial scope of judicial power is limited to the territory of the state concerned. Reversely, the pend-

\footnotetext{
${ }^{54}$ Seoul Civil District Court, 21 October 1981, Seongo 81 KaHab 949.

${ }^{55}$ Supreme Court, 15 May 1963, 63 Da 111.

${ }^{56}$ Seoul Civil District Court, 21 October 1981, Seongo 81 KaHab 949.
} 
ing of a case in another state has no effect on the exercise of jurisdiction by the Korean court. However, in light of the economy of civil litigation and judicial justice, the courts constrain that exercise by way of the recognition of foreign judgments.

This attitude is well illustrated in a decision by the Supreme Court. ${ }^{57} \mathrm{~A}$ Korean man and a Korean woman had married in Korea and had been living in New York since shortly after the marriage. The woman filed a divorce suit in a New York court. While the suit was pending, the man returned to Korea for his work and instituted another divorce suit against the woman in a Korean court. The woman did not appear in the Korean court and, consequently, did not make a plea of lis pendens. While the Korean lawsuit was pending, the New York court rendered a final judgment allowing divorce and mandating the payment of child allowance. The Korean court later rendered a judgment which was more favourable to the husband. The woman appealed to an intermediate appellate court and to a last resort appellate court. Among the grounds of appeal was the double suit plea. The Supreme Court remanded the case to the intermediate appellate court, holding as follows:

"A foreign judgment may have res judicata effect by recognition. Therefore, it is incorrect for the lower court not to have considered the possibility of recognition of the New York court judgment."

The lower court consequently decided that the judgment of the New York court had res judicata effect in Korea, as it fulfilled the requirements of Article 203 of the KCPC on recognition of foreign judgments. The man appealed but the Supreme Court upheld the decision of the lower court.

It may be inferred from this case that, although a lawsuit in a foreign country in itself does not bar an identical claim on the same facts in a Korean court, the judgment of the foreign court may affect that suit if it is rendered first and meets the requirements for recognition of foreign judgments. In considering the fulfilment of these requirements, due process and the interest of the parties, as well as the reasonableness of an exercise of jurisdiction by the Korean court are taken into account.

Some issues remain unsettled. First, it is uncertain how the new lawsuit should be dealt with while the foreign lawsuit is pending and judgment is not yet rendered. There is no judicial decision available on this issue as yet. Some scholars have argued that the Korean court should suspend the trial of the new case until the foreign court has rendered its final judgment. Others argue that suspension of the case is unnecessary and that the admissibility of the new suit should be decided later in light of the possibility of recognition of the future foreign judgment. ${ }^{58}$

\footnotetext{
${ }^{57}$ Supreme Court, 14 March 1989, Seongo 88 Meu 184, 191.

${ }^{58}$ International Civil Litigation (Korean Judicial Training Institution, 1995 no. 3) 88-89.
} 
It is also uncertain which of the decisions takes effect if a Korean judgment is rendered and becomes final while a prior foreign final judgment has remained unnoticed. Some argue that the foreign judgment will not take effect on the ground that it is in breach of public policy as it contradicts a final judgment of a Korean court. Others argue that the issue should be decided by the jori on transboundary civil litigation. ${ }^{59}$

\subsection{Immunities}

There are special circumstances, due to the special status of the party concerned, by which the forum state lacks jurisdiction although all other requirements for such jurisdiction are fulfilled. Sovereign immunity and diplomatic immunity are typical examples.

As to sovereign immunity, there is no written law on the subject, except for a reference, in Article 18(2) of the Korea-US Friendship, Commerce and Navigation Treaty, ${ }^{60}$ to the status of public entities of the US. The Article prescribes that an enterprise of one party, including a public-owned or public-controlled corporation, association, or government agency, does not enjoy tax exemption, nor immunity from judicial jurisdiction, compulsory execution, and other obligations regularly imposed in the territory of the other party on privately owned or privately managed companies, if it engages in commercial, industrial, shipping or other business activities. Three judgments deal with the sovereign immunity of foreign public entities. The first two decisions seem to follow the so-called 'absolute immunity' doctrine, while the third one seems to tend to adhere to the so-called 'restrictive immunity' theory.

First, there is a judgment of 1975 in a lawsuit against the state of Japan. ${ }^{61}$ The plaintiff was a Korean resident in Japan. He had a user right to publicowned riverside land for a sightseeing boat business. The right was repealed when the land was needed for the construction of a highway. The Japanese government did not pay any compensation, whereupon the Korean filed a claim for damages against the Japanese government in a Korean court. The defendant raised the objection of sovereign immunity, which was accepted by the Supreme Court. The reasons provided were as follows:

"Korea can not exercise judicial jurisdiction over a foreign country because it is international practice that a State does not submit to the judicial jurisdiction of a foreign country, with the exception of the existence of special treaty provisions to the contrary, or waiver by the state enjoying immunity. Such exceptions do not apply in this case."

\footnotetext{
${ }^{59}$ Ibid. 89.

${ }^{60}$ Treaty of 27 November 1956; Korean Bilateral Treaty Series, Bk. No. 2 (1940-1960) 501; TIAS 3947; 8 UST 2217.

${ }^{61}$ Supreme Court, 23 May 1975, Koji 74 Ma 281.
} 
The second decision, of 1985 , concerned a suit by a Korean citizen against Thailand. ${ }^{62}$ An officer of the Thai Embassy in Korea had borrowed money from a Korean, the alleged purpose of which was the payment of salaries to employees of the Embassy. The officer issued a pre-dated check with the seal of the Thai Embassy. On the day of payment, the Thai Embassy declined payment on the ground that the officer was not empowered to issue a check with the seal of the Embassy and had embezzled the money. The Embassy consequently claimed not to be liable for the check. The Korean creditor filed a suit against the Thai Government but the defendant pleaded sovereign immunity. The Supreme Court accepted the plea on the same reason as that provided in the case mentioned above. It added the following reasoning:
"Though there is a substantial number of countries which in their domestic laws and judicial decisions do not recognize sovereign immunity with regard to transactions of a private character, this practice has not attained the status of customary international law."

In a recent case of 1994, the Korean court seems to have changed its attitude. ${ }^{63}$ A Korean had leased an electronics shop in a US governmentmanaged hotel in Seoul. An officer of the hotel had said that due to the special status of the US Army in Korea, all goods sold in the shop were taxfree. The Korean believed this and a corresponding clause was included in the contract. As it turned out that some goods sold in the shop were not taxfree after all, the Korean filed a suit against the US Government seeking indemnity for the resulting loss. The defendant raised the sovereign immunity objection, which the Seoul District Court rejected on the following ground:

"An act of a foreign state or its agency is not always immune from the jurisdiction of the domestic court of another state. If [the act] is of a private economic or commercial character, it is not immune from the jurisdiction of a domestic court."

This being the typical argument in favour of restrictive immunity, it might be assumed that Korea has changed its attitude by following the restrictive immunity doctrine, but for the fact that the decision was taken by a lower court. Nevertheless, most authors in Korea support the doctrine of restrictive immunity. ${ }^{64}$

Diplomatic and consular immunity is covered by the Vienna Conventions on diplomatic and consular relations, and international customary law on the

\footnotetext{
${ }^{62}$ Seoul Civil District Court, 25 September 1985, Seongo 81 KaHab 5303.

${ }^{63}$ Seoul Civil District Court, 22 July 1994, 90 KaHab 4223.

${ }^{64}$ LeE SiYOON, op. cit. n. 10 p. 54; CHOI KONGWOONG, op. cit. n. 24 p. 255.
} 
matter. Korea ratified the former in 1970 and the latter in $1977 .{ }^{65}$ It should be noted that international law binding on Korea is regarded as having the same effect as domestic law in the Korean legal system.

Under Article 23 of the Korea-US Status of Forces Agreement ${ }^{66}$ the US Army and its personnel are immune from the jurisdiction of Korean courts or at least subject to special judicial procedures. The US and Korean Governments waive mutual claims for damage to military property or military personnel of the other party if the claim has arisen during the performance of official duties. In case of a claim for damage to other public property as a result of the performance of official duties, it is settled by arbitration. Claims for damage to a civilian as a result of the performance of official duties by US Army personnel are to be settled following the procedural and substantive law applicable to similar claims arising from the performance of official duties by Korean Army personnel. Claims for damage to a civilian arising from private activities of US Army personnel are to be treated as a normal civil case except that it is preceded by a special mediation procedure. Under this special procedure, the Korean government hears the case and fixes the amount of compensation. If the victim accepts the amount, the case ends there. If he refuses, a suit may be filed.

\section{SERVICE OF PROCESS}

\subsection{Service of process in general}

Korea is not a party to any treaty relating to international cooperation on service of process, although the participation in the 1965 Hague Convention on the Service Abroad of Judicial and Extra Judicial Documents in Civil or Commercial Matters is under discussion (in 1997). The only international law affecting service of process and binding on Korea is the Vienna Convention on Consular Relations. Domestic law on the matter is to be found in the $\mathrm{KCPC}^{67}$ and the International Judicial Cooperation in Civil Cases Act (IJCC) of 8 March $1991 . .^{68}$ The IJCC regulates judicial cooperation on service of process and taking of evidence. Before this Act took effect, the Supreme Court Guideline on the Treatment of Judicial Cooperation regulated the matters concerned. Article 3 of the IJCC prescribes the precedence of inter-

\footnotetext{
${ }^{65}$ See 2 AsYIL (1992) 187.

${ }^{66}$ Agreement under Art. 4 of the Mutual Defence Treaty between the Republic of Korea and the USA, regarding facilities and areas and the status of US armed forces in the Republic of Korea, 9 July 1966, Korean Bilateral Treaty Series, Bk. No. 3 (1960-1970) 695; TIAS 6127; 17 UST 1677.

${ }^{67}$ Art. 176 on Methods of Service in a Foreign Country, Art. 179 on Service by Public Notice.

${ }^{68}$ Act No. 4342.
} 
national law over domestic law in case of service of process, ${ }^{69}$ but it has no real effect, as there is only domestic law on civil judicial assistance available in Korea.

\subsection{Service of process in a foreign country for proceedings in Korea}

The request for service of process in a foreign country is made by the presiding judge of the court where the suit is pending, through the head of the court to which the requesting judge belongs, the Director of the Court Administration Office, and the Minister for foreign affairs, to the Korean consul in the foreign country or to the competent public authority of the foreign country. ${ }^{70}$

Service of process by the Korean consul is invoked if the person to be served is a Korean national residing in the foreign country, if that country is a party to the Vienna Convention on Consular Relations and if such manner of service is not contrary to that country's law or its 'declaration of intent' ${ }^{71}$ Japan is said to be the only country that has prohibited the service of process by the Korean consul on Korean nationals in its territory. ${ }^{72}$ In case of service by the Korean consul, the relevant documents are delivered directly to the person served, or by mail with attestation that the delivery has in fact taken place. $^{73}$

Service by the competent public authority of the foreign country where the service is to be made may be entrusted to the court or another official agency of that country, if the country concerned has approved by law or 'declaration of intent' to entertain such entrustment. ${ }^{74}$ Such declaration may be made expressly as well as implicitly. A translation is appended to the related documents in the official language of the country where the service is to be made or in English if the official language cannot be identified. ${ }^{75}$ The expenses for translation shall be part of the lawsuit cost. ${ }^{76}$ All other expenses

\footnotetext{
${ }^{69}$ Art. 3. In case the treaty and other international laws corresponding to it provide otherwise with respect to judicial cooperation procedures as prescribed by this Act, the former shall prevail.

${ }^{70}$ IJCC, Art. 5.

${ }^{71}$ Ibid., Art. 5(2)(1).

${ }^{72}$ See RYU YUNGIL, op. cit. n. 51 pp. 126-129.

${ }^{73}$ IJCC, Art. 8.

${ }^{74}$ Ibid., Art. 5(2).

${ }^{75}$ Ibid., Art.7(1).

${ }^{76}$ Ibid., Art. 7(4).
} 
needed for the service are to be borne by the party requesting it and the estimated amount shall be paid in advance. ${ }^{77}$

If both manners of service of process are legally or practically not possible, service by public notice is the last resort. In this case, the court official shall keep the documents to be served, and put up a corresponding notice on the court billboard. At the same time, the Korean ambassador or consul residing in the foreign country concerned is notified ${ }^{78}$ by the court, through the head of the court to which the requesting judge belongs, the Director of the Court Administration Office, and the Minister for foreign affairs. ${ }^{79}$

\subsection{Service of process in Korea for proceedings in foreign country}

The IJCC provides that all services in Korea for proceedings in a foreign country shall be done through the Korean court. The request from the foreign country is made through diplomatic channels and is assigned by the Director of the Court Administration Office to a proper court, i.e. the District Court which has jurisdiction over the place where the service is to be carried out.

Neither service by mail or personal service on the defendant directly by an authority of the foreign country, nor direct service between the parties are allowed in Korea. Yet such illegitimate ways of service are reported to be frequently used in practice ${ }^{80}$ although they may result in the refusal of recognition of the later foreign judgment. Meanwhile, some scholars argue that they should be allowed for reasons of convenience and reliability. ${ }^{81}$

In addition to service through the Korean court, service by a foreign consul on his nationals is permitted, if the country concerned is a party to the Vienna Convention on Consular Relations. Under this Convention the service of process is part of the functions of the consul. However, the service by a foreign consul on Koreans or nationals of a third country is not permitted.

Statistics about the numbers of service of process in Korea for foreign proceedings are not available ${ }^{82}$ but there are reports about entrustments from the US, Germany, Switzerland, Singapore, the UK, Canada, Turkey, Norway, Australia, Hongkong and Qatar. ${ }^{83}$

Some requirements must be fulfilled for an entrustment from a foreign country to be effective. One is that of reciprocity. There shall be either a judicial cooperation treaty between Korea and the entrusting country or a

\footnotetext{
${ }^{77}$ Ibid., Art. 9.

${ }^{78}$ Ibid., Art. 10(1).

${ }^{79}$ Ibid., Art. 10(2).

${ }^{80}$ RYU YUNGIL, op. cit. n. 51 pp. 114-117.

${ }^{81}$ Ibid., p. 119.

${ }^{82}$ Supreme Court, 12 July 1992, 92 Da 2585.

${ }^{83}$ Kukjesabubkongjoeobmucheriyokang [Handbook on International Judicial Cooperation] (Court Administration Office, 1985) 6.
} 
commitment from the entrusting country that it would in turn comply with any entrustment of judicial cooperation by the Korean court. ${ }^{84}$ Other requirements include that the entrustment may not be detrimental to the public morals in Korea; that the entrustment is made through diplomatic channels; that the entrustment of service is made in writing specifying the name, nationality, address or residence of the person to be served; that a translation in the Korean language is appended; that the entrusting country guarantees the payment of expenses needed for implementing the entrusted matters. ${ }^{85}$

\section{THE TAKING OF EVIDENCE}

\subsection{The taking of evidence in a foreign country for proceedings in Korea}

Like the service of process, taking of evidence is regulated only by domestic law. Korea is not a party to any treaty on judicial cooperation, such as the 1970 Hague Convention on the Taking of Evidence Abroad in Civil or Commercial Matters. The main domestic law is contained in the IJCC and some provisions of the KCPC ${ }^{86}$ In the absence of a treaty, the question whether the requested country entertains an entrustment for the taking of evidence depends on international comity.

The request for the taking of evidence in a foreign state is made by the presiding judge in the case at hand. As in the case of a request for service of process, the request for taking evidence is made through the head of the court to which the requesting judge belongs, the Director of the Court Administration Office, and the Minister for Foreign Affairs. ${ }^{87}$ The taking of evidence is done by the Korean consul in the foreign country or by the competent public authority of the foreign country concerned. A direct request by the parties to a foreign court or foreign authority is not permitted. The taking of evidence by the Korean consul can only take place if the person undergoing inquiry is a Korean national who is residing in the foreign country, if that country is a party to the Vienna Convention on Consular Relations, and if the mode is not contrary to that country's law or its 'declaration of intent' ${ }^{88}$ No case on the application of this procedure has been reported

\footnotetext{
${ }^{84}$ IJCC, Art. 12.

${ }^{85}$ IJCC, Art. 12.

${ }^{86}$ Art. 268(3) on Investigation of Evidence in a Foreign Country; Art. 327 on the Presumption of Authenticity of a Foreign Official Document.

${ }^{87}$ IJCC, Art. 6.

${ }^{88}$ IJCC, Art. 5.
} 
yet. ${ }^{89}$ Therefore, it is said that the only realistic way of taking evidence is by the court or other official agency of the country where the evidence is taken.

A translation must be appended to the related documents in the official language of the country where the service is made, or in English if the official language thereof cannot be identified. The expenses for the translation shall be part of the lawsuit cost. All other expenses needed for the taking of evidence are to be borne by the requesting party and the estimated amount shall be paid in advance.

The law does not exclude any kind of evidence from being acquired. There are, however, no reported cases on requests for the production of documents, the summons of a witness, or the consultations of an expert. The only form practised so far has been the questioning of persons. ${ }^{90}$

\subsection{The taking of evidence in Korea for the proceedings in a foreign country}

Taking evidence for foreign proceedings can only be done by a Korean court. The entrustment by the foreign country is made through diplomatic channels and is assigned to the proper court by the Director of the Court Administration Office. ${ }^{91}$ This is the District Court having jurisdiction at the place where the evidence or the other objects to be verified or appraised are located..$^{92}$

In order for the entrustment by the foreign country to be entertained in Korea, there shall be either a judicial cooperation treaty on which the entrustment is based or a commitment by the entrusting country that it will comply with any entrustment by the Korean court. In addition there are the following other requirements:

"The taking of the evidence in question must not be detrimental to the public
morals of Korea; the entrustment is made through diplomatic channels; the
entrustment is made in writing specifying the party, a summary of the case,
the kind of evidence, the name, the nationality, the address or residence of
the person to be heard and the matters to be inquired in case of the hearing of
a witness; a translation in the Korean language must be appended; the en-
trusting country guarantees the payment of expenses needed for the imple-
mentation of the entrusted matters."

The law does not prescribe any restrictions as to the methods of evidencetaking such as the production of evidence, the consultation of experts, and

\footnotetext{
${ }^{89}$ RYU YUNGIL, op. cit. n. 51 p. 162.

${ }^{90}$ Ibid.

${ }^{91}$ IJCC, Arts. 13 and 14.

${ }^{92}$ IJCC, Art. 11.

${ }^{93}$ IJCC, Art. 12.
} 
the hearing of witnesses or the party concerned.${ }^{94}$ However, as is shown in the following case, one may presume that entrustment of compulsory evidence examination is not entertained in Korea. A German court requested the blood sampling of the defendant in a German proceeding for the determination of a child-father relationship. The entrustment said that compulsory blood sampling was a permissible method of collection of evidence under German law if the defendant refuses to render cooperation voluntarily. The Korean court sent a summons to the defendant, who refused to appear. It thereupon terminated the procedure and concluded on the impossibility of the taking of evidence. ${ }^{95}$

\section{RECOGNITION AND EXECUTION OF FOREIGN JUDGMENTS}

Korea is not a party to any treaty on recognition and enforcement of foreign judgments, and one therefore has to turn to domestic law to look for an answer to the question of recognition and execution of foreign judgments. Recognition is dealt with in Article 203 of the KCPC and execution in Articles 476 and 477.

A foreign judgment is recognized or executed after it is confirmed that it meets the formal requirements set by the law without inquiry into its contents. In deciding whether a foreign judgment meets the public policy requirement, its contents may, however, be considered. ${ }^{96}$ By recognition, the foreign judgment obtains an effect identical to that of final and conclusive judgment in the country where it was rendered. The requirements for recognition of foreign judgments are as follows (Art. $203 \mathrm{KCPC}$ ):

"A foreign judgment which is final and conclusive shall be valid only upon the fulfilment of the following conditions:

1. The jurisdiction of the foreign court is not denied by domestic or treaty law;

2. The defeated defendant, if he is a citizen of Korea, has received the summons or any other orders necessary for the commencement of the suit through other than public notice, or has voluntarily responded to the claim without such notice;

3. The foreign judgment does not violate good morals and the social order of Korea; and

\footnotetext{
${ }^{94}$ RYU YUNGIL, op. cit. n. 51 p. 159.

${ }^{95}$ Family Court, 89 Cheu 1 Kongjosakun [Cooperation case].

${ }^{96}$ CHOI Kongwoong, op. cit. n. 24 p. 401.
} 
4. There is mutual guarantee." 97

A foreign judgment must be final and conclusive in order to be recognized. Any kind of final and conclusive judicial decision having the character of a judgment is considered to meet this requirement, regardless of its name and format. ${ }^{98}$ The finality, conclusiveness and judgment character of the foreign judicial decision are determined by Korean law. 'Conclusive' means that no further general remedy is available to the defeated party to obtain a change of the judgment. 'Final' means that no further court action is required to declare the matter exhaustively adjudged. 'Judgment' means an official decision of the court on the claim object of the litigation. Usually, it is rendered at the end of the proceedings, but it may be rendered in the middle of the proceedings if there are several claims and if an intermediate judgment is necessary for the further proceedings. No differentiation is made between the different types of judgment: execution judgment, declaratory judgment, or judgment changing the legal status of the parties.

The requirement of international jurisdiction of the foreign court is called 'indirect international jurisdiction'. As mentioned above in section 3.1., its criteria are the same as that of direct international jurisdiction. This is illustrated by a decision of the Supreme Court of 1988 on the recognition of a foreign divorce judgment. In that judgment, the Supreme Court reiterated the reasoning provided in its decision on direct international jurisdiction, as follows:

"In transnational divorce cases, the issue of the international jurisdiction of the foreign court should be decided by such criteria as the fair and just settlement of the case and the policy consideration of the recognition of a foreign judgment. In light of these criteria, international jurisdiction is exercised by the courts of the country where the domicile of the defendant in the international divorce case is located, except in special circumstances, such as unknown place of domicile or voluntary response by the defendant so that the exercise of jurisdiction does not breach his due process rights." 99

In a 1995 case on the recognition of a product liability judgment by a court in Florida, USA, the Supreme Court repeated the above reasoning. It is interesting that the Supreme Court also applied the criteria of the reasonable expectation of the defendant and of the substantial connection, similar to those applied in the US legal system. It held:

"In product liability cases, jori demands that the question of whether to exercise international jurisdiction should be decided by taking into account the reasonable expectation of the producer that damage might arise and that a suit

\footnotetext{
${ }^{97}$ This Korean term has a meaning different from 'reciprocity'. It is deemed to be met if the other country recognizes and executes Korean judgments under the same or more favourable conditions than those in Korea.

${ }^{98}$ ChOI Kongwoong, op. cit. n. 24 p. 396.

${ }^{99}$ Supreme Court, 12 April 1988, Seongo 85 Meu 71.
} 
might be filed at the place where it is in fact instituted, and the existence of a substantial connection between the producer and the place where the damage occurred. In determining this connection, an important factor is provided by the acts of the producer which are consciously aimed at obtaining business profit in that very place. . . . The facts in the present case show that there was no such reasonable expectation or substantial connection." 100

The requirement of service of process applies only when the defeated defendant holds Korean nationality. Its purpose is to guarantee the right of Korean citizens to proper notice of the commencement of a case. Thus, the requirement is interpreted to include the prohibition of service by public notice and any other extraordinary mode of notice. ${ }^{101}$ Notice by mail to a Korean national residing in Korea is considered to be such an extraordinary mode, even though it is a legitimate mode of notice under the law of the country where the judgment has been rendered. ${ }^{102}$ As to voluntary response in case of absence of notice, it is interpreted to include not only general appearance but also special appearance, as the requirement is deemed to be fulfilled by the mere fact that the defendant knew about the filing of the suit. ${ }^{103}$

The public policy requirement is applied in extraordinary situations where the international comity of recognizing foreign judgments gives way to the public policy of the forum state. ${ }^{104}$ Public policy here is interpreted to include procedural justice as well as substantive justice.

Finally, the 'mutual guarantee' requirement is deemed to be satisfied if it can be shown that a Korean judgment would be recognized in the state of the original court under the same or more favourable conditions. ${ }^{105}$

A foreign judgment may be executed only after its validity has been pronounced by an execution judgment (exequatur) of a Korean court. ${ }^{106}$ As to jurisdiction to render an execution judgment, Article 476(2) of the KCPC provides that an application seeking an execution judgment falls under the jurisdiction of the District Court located at the place of the general forum of the debtor. Where there is no such general forum, it falls under the jurisdiction of the court of the place where the property of the debtor is located. The

\footnotetext{
${ }^{100}$ Supreme Court, 21 November 1995, Pangyul [Judgment] P3 Da 33607.

${ }^{101}$ Supreme Court, 3 December 1968, Pangyul 68 Da 1929. This judgment stated that "[i]t does not meet the requirement for a service of process if notice is given at an old office where no member of the defendant is present".

${ }^{102}$ CHOI Kongwoong, op. cit. n. 24 p. 399.

${ }^{103}$ Ibid., p. 400.

${ }^{104}$ Seoul High Court, 14 February 1985, Seongo 84 Na 4043.

${ }^{105}$ E.g., Supreme Court, 22 October 1971, Seongo 71 Da 1393; Supreme Court 28 April 1987, Seongo 85 DaKa 1767

${ }^{106} \mathrm{KCPC}$, Art. 476(1)
} 
competent District Court has jurisdiction over all kinds of foreign judgments including those on issues of family law. ${ }^{107}$

An execution judgment is rendered upon fulfilment of the formal requirements, without considering the contents of the foreign judgment. These requirements are the same as those on recognition and are contained in Article 477 of the KCPC:

"(1) An execution judgment shall be rendered without inquiring into the propriety of the foreign judgment;

(2) An application for an execution judgment shall be rejected in the following instances: (i) if it has not been proven that the foreign judgment has become final and conclusive; and (ii) if the foreign judgment does not fulfil the conditions required by Article 203."

\section{ARBITRATION}

Korea is a party to the UN Convention on the Recognition and Enforcement of Foreign Arbitral Awards (New York Convention) ${ }^{108}$ and the Convention on the Settlement of Investment Disputes between States and Nationals of Other States (ICSID Convention). The most important domestic law on arbitration is the Arbitration Act ${ }^{109}$ which applies to both domestic and international arbitration. A treaty duly concluded and published has the same effect in the Korean legal order as a statute. Since the conventions relating to international arbitration are lex specialis, they have priority over the Arbitration Act. Therefore, the Arbitration Act applies to international arbitration only if there are no treaties applying to the case or if there is no treaty provision applicable to the case. ${ }^{110}$

An international arbitration agreement is respected in Korea and a foreign arbitral award is recognized and executed if it fulfils the requirements of either of the above Conventions. The details are beyond the scope of this paper. Mention will, however, be made of the provisions necessary to obtain some insight into the requirements for an arbitration agreement to be respected and for an arbitral award to be executed.

\footnotetext{
${ }^{107}$ Supreme Court, 28 December 1982, Pangyul Meu 25; Seoul High Court, 3 May 1982, Seongo 82 Reu 5.

${ }^{108}$ The Republic of Korea made a commerce and a reciprocity reservation upon ratification of the New York Convention.

${ }^{109}$ Act No. 1767 of 3 March 1966.

${ }^{110}$ LEE HOWON, 'Oykukjungjepanjeongeui Seunginkwa Jiphaeng' [Recognition and execution of foreign arbitral awards], in Seopoisabubeui Jemunje [Legal problems of transnational transactions] (Court Administration Office, 1986) 663; HONG CHANGSIK, Oykukjungjepanjeongeui Seunginkwa Jiphaenge Kwanhan Kukjeyeonhabhyubyak Haeseol [Commentary on the New York Convention] (Korean Arbitration Institute, 1972) 41.
} 
An arbitration agreement shall be made up in writing, or stipulated in a contract or contained in an exchange of correspondence or telegrams. ${ }^{111}$ No arbitration agreement is allowed regarding matters which are not at the disposal of the parties. These matters of public interest include patent disputes and antitrust disputes. The existence of a valid arbitration agreement bars the institution of a lawsuit. ${ }^{112}$

Acts or matters which the arbitrator deems necessary for an arbitral award but which he cannot directly perform, shall be performed by the Court at the request of the arbitrator or the parties concerned. ${ }^{113}$ An arbitrator may proceed with an arbitration procedure and deliver an award, even if a party challenges the validity of the arbitration agreement, or contends that the arbitration agreement has no relevance to the dispute, and/or that the arbitrator has no authority. ${ }^{114}$

An arbitral award shall have the same effect between the parties as a final court judgment. ${ }^{115}$ An application for the annulment of an arbitral award may be filed on any of the following grounds within certain peremptory terms ${ }^{116}$ :

"1. The selection of the arbitrators or the determination of the arbitration rules of procedure have not come about in accordance with [the . . . Act] or with the arbitration agreement;

2. In the process of selecting the arbitrators or the determination of the arbitration rules of procedure, a party was incompetent or his representative was not lawfully designated;

3. The contents of an arbitral award requires an action which is prohibited by law;

4. The parties have not been examined properly in accordance with the arbitration procedures; or the arbitral award is not properly reasoned;

5. The case falls under items 4 through 9 of Article 422 of the Code of Civil Procedure."

The right to apply for annulment of the award lapses upon agreement reached on the dispute relating to the above-mentioned item $4 .{ }^{117}$ The compulsory

\footnotetext{
${ }^{111}$ Arbitration Act, Art. 2.

${ }^{112}$ Arbitration Act, Art. 3.

${ }^{113}$ Ibid., Art. 9.

114 Ibid., Art. 10.

${ }^{115}$ Ibid., Art. 12.

${ }^{116}$ Ibid., Art. 13(1).

${ }^{117}$ Ibid., Art. 13(2).
} 
execution of an arbitral award may only take place after its validity has been affirmed by an execution judgment. ${ }^{118}$

${ }^{118}$ Ibid., Art. 14. 